\title{
Changing Context, Persistent Frames: The United States and the Absence of Multilateral Institutions in Post-Cold War East Asia
}

\section{CLINT WORK*}

\begin{abstract}
After the Cold War, conditions appeared ripe for the formation of new multilateral institutions that would have more accurately reflected the altered distribution of power in East Asia. However, no new or robust institutions were established. Despite the value of certain historical and structural arguments, this study emphasizes the role of the United States in contributing to this outcome. Building upon critical historiography, this article sketches three frames of U.S. foreign policy held by U.S. elites (including: expansion, preponderance, and exceptionalism), traces their operation in the discourse and rationales behind U.S. policy during the post-Cold War interregnum, and argues that these frames worked against any attempt by the United States to establish new multilateral institutions.
\end{abstract}

Keywords: Critical Historiography, U.S. Foreign Policy

Frames, Post-Cold War Interregnum, Economic

Expansion, Preponderance, American

Exceptionalism, Hierarchy

* Ph.D. Candidate, University of Washington, Seattle, USA;

E-mail: workj@uw.edu

DOI: 10.16934 isr.17.1.201606.77 


\section{INTRODUCTION}

\section{Puzzle}

In the late twentieth century, conditions appeared ripe for the formation of new multilateral institutions that would have more accurately reflected the altered distribution of political, economic, and military power in the international system generally and East Asia more specifically. Several factors contributed to this new context, including the remarkable growth and industrialization of various East Asian countries, their gradual integration into the global political economy during the Cold War, and the profound transformation of the strategic global and regional landscape at the end of the Cold War (Hellman 2003).

However, either no new institutions were established, or where an attempt was made, as in the case of the Asia-Pacific Economic Cooperation forum (APEC), the effort was too narrowly focused and lacked a formal framework for institutional deepening. First, APEC dealt with purely economic rather than political or security issues. Second, and more importantly, APEC was built upon consensual, marketinduced integration rather than politically driven, policy-induced integration (Gilpin 1997). The lack of new or robust multilateral institutions remains the case today, nearly three decades after the end of the Cold War.

\section{Alternative Explanations, Frames, and Organization}

There are various structural and historical arguments for why no new institutions were created. First, unlike past transitional periods (i.e., the Napoleonic Wars, World War I, and World War II) a hegemonic war had not been the cause of systemic change, catalyzing the formation of new institutions. As Gilpin (1981, 42-43) notes, "the evolution of any system has been characterized by successive rises of powerful states that have governed the system and have determined the patterns of international interactions and established the rules of the system. Thus the essence of systemic change involves the replacement of a declining dominant power by a rising dominant power." On the international level, this occurs through "revolutionary change" in the form of hegemonic war, the objective of which is to remake the governing rules and institutions of the system to suit the interests of the newly powerful states or a hegemon (47). However, the end of the Cold War witnessed the victory of an already dominant power without a resort to war, as a result of which its vision of political modernity and preferred rules of the system appeared secure.

Second, the larger number of players who demanded and could be "expected to play a role in laying the foundations of a new international order" made the building of such an order even more complicated (Gilpin 1997, 16). In fact, this 
had already begun to cause problems within existing institutions, as evidenced by increasing difficulty in successive multilateral trade rounds within the GATT/ WTO and the corresponding rise of Preferential Trade Agreements (PTAs) in place of multilateral trade integration (Gruber 2001). Third, the relative shift in the distribution of economic and military power, away from Western Europe and the North Atlantic and toward East Asia, was complicated by the reluctance on the part of Western industrial powers to relinquish their longstanding predominance of the international system and accommodate these new realities. Distinct cultural, political, social, and historical perspectives exacerbated the process of accommodation (Gilpin 1997). Fourth, the economic growth and modernization of East Asian states occurred within a larger U.S. hegemonic structure, which distorted both their ability and willingness to take on a new role in the international system (Hellman 2003).

These various arguments are valuable and compelling. Without discounting their validity, this article shifts the focus to what Hellman $(2003,38)$ calls "the most important feature of this system," namely, the absence of an effort on the part of the United States to attempt to create new institutions in order to manage the radically different distribution of power at the end of the Cold War. Rather than a refutation of the arguments outlined above, the present analysis aims to situate U.S. policy within this larger constellation of historical and structural variables. Thus, the central inquiry is: Why did the U.S. not attempt to create institutions to manage the new power distribution in East Asia after the end of the Cold War?

This begs the question(s): Why were new institutions needed? Why was establishing new institutions an appropriate policy option for the region and the U.S. more specifically? Following Ikenberry (2001), there are several interrelated reasons why new institutions were both necessary and potentially viable. First, the international context at the time increasingly exhibited low returns to power and high returns to institutions (Ikenberry 2001). The rise in the number of new countries and nationalisms since the last postwar settlement; the proliferation of nuclear weapons; the industrialization and entry of numerous states into the global economy; as well as the emergence of new transnational and non-traditional security threats were a few factors that made coercion more costly and the benefits of (and need for) cooperation more apparent. Furthermore, Ikenberry highlights that one of the fundamental features of the prevailing order, particularly among the advanced industrial countries, was how the structure of relations between them was deep and pervasive, which was itself an outgrowth of profoundly robust institutions (Ikenberry 2001). Pointing to this example, Howe $(2007,19)$ highlights that the "institutionalization of multilateral security cooperation has been hailed by liberal modernists as a model that contributes to the resolution of existing conflicts and the generation of a more peaceful internal society." In the context described above, with coercion costly and cooperation attractive, the extension of such constitutional arrangements 
made sense.

Second, though not the consequence of a hegemonic war, the dissolution of the bipolar divide did result in a fundamental reordering in the international system, both in terms of the balance of power and also in regard to the contest over separate visions of political modernity. The remarkable shift left the United States in a position of "unrivaled global power" (Ikenberry 2001, 258). Building off Keohane (1984), who argues that institutions matter most after hegemony, Ikenberry $(2001,17)$ shows they are also critical "at the beginning of hegemony-or "after victory'-in establishing order and securing cooperation between unequal states." Again, the U.S. was not a new hegemon, but the end of the Cold War was a kind of victory that opened space for what might be called the reestablishment or recalibration of hegemony through a new institutional bargain, particularly in East Asia.

In short, there remained a large enough asymmetry of power between the U.S and weaker or smaller states in the region to motivate the "institutional mode of order building" (Ikenberry 2001, 258). In this bargain: "the leading state agrees to restrain its own potential for domination and abandonment in exchange for greater compliance by subordinate states. Both sides are better off with a constitutional order than in an order based on the constant threat of the indiscriminate and arbitrary exercise of power" (258-259). Moreover, for the Americans, pursuing such an arrangement would have been the optimal way to cement its place in the post-Cold War period, due to the inherent legitimacy it would gain by binding itself and institutionalizing the exercise of its power. The ability to restrain and commit its power credibly is itself, paradoxically, "a type of power," in that it serves as a bargaining chip that can lock in the commitment of other states (259). However, a key condition is that the leading state be inclined toward and fully commit itself to this inherently difficult process.

However, as is known, the U.S. was not so inclined and did not attempt to establish new multilateral institutions in post-Cold War East Asia. The intent here is to identify several key frames of U.S. foreign policy that help explain why the United States did not attempt to do so. The term frames refers to collective, inter subjective understandings or beliefs that actors use to construct roles and interpret the world (Goffman 1974; Weick 1995; Autesserre 2009). These understandings not only exist within individual heads, but are also embedded in historical process, social discourse, practice, and institutions (Jervis 2006; Autesserre 2009). Frames can both pre-exist action as well as emerge and be reconstituted through practice. This article sketches several key frames held by U.S. policy elites, which take the form of general imperatives for U.S. foreign policy (i.e. economic expansion and preponderant power) and a guiding ideology (i.e. exceptionalism) that underpin the U.S. role in the world. Using these frames, the article traces, in a relatively broad manner, their operation in the discourse and rationales guiding U.S. foreign 
policy toward East Asia in the post-Cold War interregnum(from the late 1980s to the mid-2000s). In short, these frames worked against any attempt by the United States to establish new multilateral institutions.

This sketch builds upon critical historiography of U.S. foreign policy. From this scholarship, three interconnected and historically rooted frames of U.S. foreign policy are identified, including: 1) a guiding faith in laissez faire, free-market capitalism and an attendant need for market expansion; 2) an ineluctable drive toward preponderant global power, both in economic and military terms; and 3) an ideology of exceptionalism, often manifest in contradictory and coercive ways. In sum, the lack of U.S. initiative in devising new international institutions may be remarkable, but in light of these frames it is hardly surprising.

The article proceeds as follows. First, each frame is delineated through use of critical historiography of U.S. foreign policy. Second, U.S. policy in East Asia during the post-Cold War interregnum is examined, with particular focus on how these frames were manifest in U.S. security policy as well as in the U.S. response to the East Asian economic crisis. Third, qualifications to the argument are provided, before then turning to a brief examination of the frames vis-à-viscurrent U.S. policy. Fourth, and by way of conclusion, we return to Ikenberry (2011) in order to provide further support for the sketch above.

\section{CHARACTERISTICS OF US FOREIGN POLICY: HISTORICALLY ROOTED AND INTERTWINED}

\section{Faith in Markets and the Pressure Valve of Expansion}

The first frame of U.S foreign policy is an abiding faith in free-market capitalism and a related drive toward continuous market expansion. This expansion consists of two parts. The first involves increasing U.S. economic prosperity (through the acquisition of territory, resources, markets, and influence), the second the gradual and unencumbered spread of the market mechanism itself. The need for continued expansion emerged from the United States' own domestic development or "march to the internal frontier," which allowed a "settler society to escape the contradictions of race and class of an emergent capitalist economy" (Anderson 2003, 34).This was extended across the Pacific "in the drive for an Open Door empire of commerce, and then in the fuite en avant of a bid for global domination that could not brook even a defensive Soviet Union" (34). This argument found its most original and forceful expression in the work of William Appleman Williams (1961, 2007, 2009) and that of his students, including Lloyd Gardner (1993), Walter LaFeber (1997), and Thomas McCormick (1995), as well as the work of Gabriel Kolko (1968).

For the U.S. and its power elite, free enterprise and the prosperity to which it 
gave rise was the basis of all other freedoms, whereas economic stagnation fostered internal unrest and raised "the specter of chaos" (Williams 1961, 354). As Williams argues, economic expansion "provided the sine qua non of domestic prosperity and social peace" (355). Thus, a vital imperative of U.S. foreign policy from the late nineteenth century forward included the opening and stability of overseas markets. Domestic tranquility was inextricably bound up with external realities. Any threat to the health of the international economy, whether in the form of autarkic trade blocs, economic depression, or the spread of an alien ideology, was therefore seen as a threat to the United States.

Following World War II, this imperative took on a new and more expansive scope, as the United States alone was capable of assuring the preservation and extension of free enterprise worldwide. Kolko (1968) highlights the several key challenges the United States faced. First, among U.S. elites there were fears regarding a return to economic depression in the wake of wartime demobilization and a resultant rise of leftist movements. Second, and related, the Soviet Union posed a potential threat, both as an antithetical version of political modernity and economic development as well as a source of support for leftist movements elsewhere. Third, there was the issue of negotiating the U.S. relationship with Great Britain, as the former replaced the latter in the role of hegemonic guarantor of the world economy.

Above all, though, the imperative of ensuring economic stability and restarting growth drove U.S. policy. As Secretary of State Dean Acheson noted in closeddoor testimony to the Senate Foreign Relations Committee in early 1950: "Even if there were no Russia, even if there were no communism ... we would have very grave problems in trying to exist and strengthen those parts of the free world which have been so badly shaken by the war and its consequences" (Cited in LaFeber 1997, 278). Regardless of the Soviet Union's existence, the imperative of averting even worse economic depression in Europe was of primary importance. Acheson, among others, believed that the American economy could not function without the opportunity for external expansion, and that the American political system could not operate without the prosperity to which such expansion gave rise (Williams 2009). Economic breakdown in Europe was an "externalized evil" that had direct consequences for domestic conditions within the U.S. (Williams 2009, 88).

\section{2) American Preponderance, for its Own Sake}

By the mid-1940s and in the wake of World War II, the United States did indeed face an uncertain world, and national security took on increased importance. Here is the second frame of U.S. foreign policy, namely, the seemingly ineluctable drive toward preponderant global power to ensure national security. However, one 
should not mistake as the ultimate driver of U.S. foreign policy the perceived need for military security per se. Anderson puts it well: "The organization of the postwar discourse of empire around security did not, of course, mean that the foundational themes of America patriotism were eclipsed by it ... [t]he primacy of security after 1945 altered the hierarchy of appeals without purging them" (Anderson 2013, 31). Thus, rather than eclipsing them, security concerns became intertwined with preexisting economic and ideological perspectives.

In fact, as Paul Nitze, principle author of NSC-68, remarked: American economic policies and the military containment of communism "were viewed as being one and the same thing" (Cited in LaFeber 1997, 295). Caldwell (2011) argues that the plan for massive rearmament and military Keynesianism embodied in NSC-68 was less about containment and more about sparking the recovery and growth of the global economy, upon which U.S. prosperity itself depended. NSC68 itself notes: "the economic effects of the program might be to increase the gross national product by more than the amount being absorbed for additional military and foreign assistance purposes" (Cited in Bacevich 2008, 110). In the minds of U.S. elites, this meant that the U.S. "could afford both guns and butter-indeed, producing more guns might actually yield more butter" (110). For them, the primary goal was to secure and maintain a preponderant global position based on both military and economic rationales.

This argument is adopted from Leffler (1992), whose work on the subject is one of the most detailed and thorough of its kind. According to Leffler, power consisted of a combination of economic and military strength, and security was determined by how this combination affected overall "power relationships" (496). The contention is not that Soviet power and actions did not figure in American thinking; of course they did. Rather, the claim is that U.S. policy was aimed toward maintaining a global balance in its favor, for its own sake, not as an insecure or defense reaction to Soviet machinations, as John Lewis Gaddis (1983) argued. Traditional or orthodox accounts, to which Gaddis (1997) returned, placed the blame for the Cold War on the Soviet Union's expansionist policy in Eastern Europe and its domestic ideological origins. According to this perspective, Soviet domestic ideology was rooted in longstanding Czarist tendencies toward expansionism, mixed with Stalinist totalitarian practices. Kennan's Long Telegram (1946) and his "Sources of Soviet Conduct" (1947) represented the official US government view at the time and the basis for the orthodox interpretation of events. Gaddis (2004) saw the formation of U.S. security policy and grand strategy, in this context and historically, as driven by external attack and the insecurity to which it gave rise, not as an outgrowth of internally rooted expansionist tendencies or an inherent drive for power.

U.S. decision makers undoubtedly focused on the ideological and psychological sources of Soviet motivations, took Soviet ambitions to be unlimited, and 
discounted the possibility of resolving differences with the Soviets. Nevertheless, the United States still stood in a far more secure position, and was determined to strengthen its hold over four of the world's five advanced industrial structures in order to maintain it. On the one side, this included the United States, Great Britain, Western Europe, and Japan; on the other side, the Soviet Union by itself (Cumings 2010). Future Soviet power and the threat of miscalculation were part of American thinking, but behind this was an inbuilt consciousness of American power and the desire to retain its preponderant position. In other words, containment provided the context and justification for a preexisting inclination.

The objective of preponderance had two parts. First, to defend the nation against external attack, the U.S. required an extensive forward military presence, insofar as any future threat could come from a great distance, as evinced by Pearl Harbor and World War II. Second, a forward presence would foster stability, promote U.S. economic interests by ensuring access to foreign markets and raw materials, and protect crucial air and sea routes (Pettyjohn 2012). For instance, the importance of Middle Eastern oil to U.S. strategists was apparent even before World War II ended. A critical early juncture in this regard was President Roosevelt's meeting with Ibn Saud on Great Bitter Lake in February 1945, setting in place the quid pro quo of American security for Arabian oil (Yergin 1991). These twin objectives of forward defense and economic stability were clearly reflected in the plan for a "perimeter defense in depth," contained in successive basing studies, JCS 570/2 and JCS 570/40, completed by the U.S. Joint Chiefs of Staff in 1943 and 1945, respectively (Pettyjohn 2012, 49). The plan was later expanded and solidified into a new policy of "consolidated defense in depth" following the outbreak of Korean War (62). Indeed, it was the Korean War that, in Acheson's words, "came along and saved us" (Cited in LaFeber 1997, 283). Not only did the war justify global basing strategies: it also catalyzed the military Keynesianism ofNSC-68; institutionalized the national security state at home; and spawned a military-industrial complex that remains influential to this day (Hogan 2000; Pierpaoli 1999).

It is critical to note that the U.S. drive for preponderant power embodied in its global basing system consisted of dual dimensions. This included the aforementioned containment or contest-of-power dimension, but also a hegemonic or relation-of-domination dimension (Kwon 2010). On the one hand, the U.S. was engaged in a contest of power against the Soviet Union. On the other hand, the relation-ofdomination element entailed unequal, hierarchical relations of power "among the political communities that pursued or were driven to pursue a specific path of progress within the binary structure of the global order" (cited in Kwon 2010, 2). For the U.S., this meant controlling the movement of resources in order to secure supremacy against any challenge from its own allies as well setting very clear boundaries to their actions (Cumings 1992). In South Korea, for instance, this was 
readily evident in the U.S. retention of the operational control (OPCON) of the Republic of Korea (ROK) military codified in the Agreed Minute to the 1954 U.S.-ROK Mutual Defense Treaty, its significant influence over ROK military commanders, and in its plans to take President Rhee into protective custody if he disobeyed U.S. policy directives (Na 2006).

The latter element of U.S. preponderance not only propelled the Cold War system, but also outlived its dissolution and that of containment itself. In this vein, McCormick refers to the Cold War as "merely a sub-plot" within the larger history of American global domination (McCormick 1995, xiii). Similarly, Anderson observes that: "the exigencies of the struggle against communism, all-consuming as these became, were only one, if protracted, phase within a larger and wider arc of American power-projection, which has outlived them by half as many years again" (Anderson 2013, 34). In other words, the U.S. drive toward global preponderance may have blossomed in the context of a bipolar confrontation, yet it contained its own internal thrust, which has since extended beyond the historical conjuncture of the Cold War. The persistence of the desire for preponderance would be evident in U.S. policy toward East Asia during the post-Cold War interregnum, complicating the establishment of new multilateral institutions that would have more accurately reflected the remarkably altered distribution of political, economic, and military power in the region.

\section{3) American Exceptionalism: Teleological Inevitability, Forceful Voluntarism}

The third frame of U.S. foreign policy is an ideology of American exceptionalism that has been internalized by and is often expressed by U.S. policy elites. Much like its Communist other, the American variant of exceptionalism exhibited a contradictory mix of teleological certainty combined with forceful voluntarism. According to Niebuhr (2008), the inherent contradictions of the United States' early development were laid bare during the Cold War, as the U.S. was confronted with a Soviet ideology and state that was borne of the same philosophical roots (i.e. classical liberalism) and that shared a history of territorial growth and aggrandizement.

Several critical historical approaches have reassessed the Cold War, arguing that rather than a strictly geostrategic or security-driven standoff, the bipolarization of global politics had its roots in the ideological bifurcation and mirroring of the two emerging continental states (Kwon 2010). Leffler (1994) challenges the conventional narrative by placing the roots of the bipolar standoff in the period after the Russian Revolution of 1917. Williams (2007) places the origins even further back, claiming the Cold War emerged from the nineteenth-century contest between the established European imperial powers and the rising America one. Kwon sums it up well: 
Leffler's scheme foregrounds the importance of ideology (the antagonistic view to communism as a radically alien way of life incompatible with the market based liberal world) in the construction of the cold war global order, whereas Williams shows how the perception of the alien ideological other mirrored for the United States at the turn of the twentieth century the nation's own ideological self-image defined in terms of so-called Manifest Destinythe idea that America, as a sole benevolent and progressive power, confronts the backward and confused world infested with imperialist excess and colonial miseries (Kwon 2010, 3).

The exceptionalist belief, in short, is that the American system of free enterprise and liberal democracy is the ultimate stage of civilization, toward which all societies must ineluctably move. The United States, having already reached this stage, is the indispensable nation able to lead others (if necessary, through coercion or violence) to this inevitable point of human liberation.

Hunt (1999), also grounding the exceptionalist ideology deep in American history, shows how it coalesced into three core ideas, including: a vision of national greatness actualized in an active quest to promote liberty; a classification of the world into racial hierarchies; and strict limits on acceptable socio-political change and economic modernization. Kramer (2006) shows how this complex mix of factors validated U.S. colonization of the Philippines and the creation of racially tiered, internal colonies within it. Similarly, Kindig (2014) contends that the U.S. project for liberation and democracy in Korea justified enormous racial and sexual violence, which through a process of historical forgetting sustained U.S. empire and similar violence elsewhere.

Crudely put, societies that differ from the American example or, what is worse, oppose it, are seen as aberrations; they are inherently illegitimate by their inability or unwillingness to change. Stephanson captures an essential sentiment of the exceptionalist creed: "What is not like the United States can, in principle, have no proper efficacy. It is either a perversion or, at best, a not-yet" (Stephanson 2011, 177-178). This was manifest in contradictory ways from the center to the periphery. On the central European front, the confrontation was marked by a sort of undeclared, even metaphorical state of war (Kwon 2010). There, the confrontation was as much about power as it was meaning, between two competing teleological systems of historical progress (Kwon 2010; Laidi 1998). However, in the Third World, where many countries faced a complex process of decolonization alongside U.S.-led efforts at state-building, there was both ideological bifurcation as well as exceptional forms of political violence (McMahon 2013; Westad 2005; Cumings 1992). Ekbladh (2011) shows how American modernization programs, driven by the gospel of liberalism, aimed to remake societies in the U.S. image. When these efforts were inevitably opposed, American exceptionalism justified horrific violence 
as a purifying force. Americans had to destroy villages to save them (Turse 2013). Although modernization theory would be discredited by the failure in Vietnam, the assumptions underpinning it would later remerge in the Global War on Terror and the Bush Administration's messianic plans to remake the Middle East (Ekbladh 2011; Bacevich 2008).

In any case, the end of the Cold War and the dissolution of the Soviet Union marked the (inevitable) vindication of American power and meaning. Liberalism was triumphant (Gaddis 1992; Kwon 2010). Thus, the remarkable change in the international system, rather than sparking a reassessment of the American vision, reaffirmed and strengthened it.

Our response ... is shaped by what we are as a people, for our values are the link between our past and our future, between our domestic life and our foreign policy, between our power and our purpose. It is our deepest belief that all nations and peoples seek political and economic freedom; that governments must rest their rightful authority on the consent of the governed, and must live in peace with their neighbors. The collapse of the Communist idea has shown that our vision of individual rights - a vision imbedded in the faith of our Founders - speaks to humanity's enduring hopes and aspirations (White House 1991, v).

The U.S. now had the opportunity and aspired to build a "new world order ... a new international system in accordance with our own values and ideals, as old pattern and certainties crumble around us" (v). The task was for us, "our generation in America and the world," thus fusing American ideals and values with the "world community" (v). Furthermore, "in doing this, American leadership is indispensable" (v). The ideology of American exceptionalism, like the other two frames above, would become evident in the formation of post-Cold War U.S. policy toward East Asia and helps to explain why the United States would not attempt to create new multilateral institutions. In what follows, U.S. security policy in the post-Cold War interregnum and the U.S. response to the East Asian economic crisis are examined in turn.

\section{POST-COLD WAR INTERREGNUM: SECURITY AND EXPANSION, HAND IN HAND}

\section{1) The Indispensable Nation: Preponderance Without a Peer-Competitor}

In the early post-Cold War period and following the dissolution of the Soviet Union, plans emerged concerning the restructuring and drawdown of Cold War era forward deployments. These plans included the Nunn-Warner Amendment (1989), 
the East Asia Strategic Initiative (EASI) (U.S. DOD 1990), and the Base Force and Bottom up Review under the Bush and Clinton Administrations, respectively (Larsen et al. 2001; Kwak 2006). They had direct implications for U.S. forces and alliances in East Asia. For example, the Nunn-Warner Amendment, among other changes, called for a reduction in the United States Forces Korea (USFK). Following this, the EASI established a more concrete ten-year plan during which U.S. forces in East Asia would be reduced and modernized over three successive phases.

However, following the initial phase, these plans were put on hold. While the first North Korean nuclear crises provided one reason, the delay was justified by reference to other longstanding rationales regarding stability, economic growth, and the requisite need for preeminent U.S. power to assure them both. The 1994 United States Security Strategy for the East Asia-Pacific Region (U.S. DOD 1995), otherwise known as the Nye Report, after Assistant Secretary of Defense Joseph S. Nye Jr. who supervised it, was representative of this shift back to the past.

The Nye Report postulated that: 1) for "the security and prosperity of today to be maintained for the next 20 years, the United States must remain engaged in Asia," including the continued stationing of 100,000 troops and strengthening of bilateral alliances (Johnson 1995, 104); 2) "United States interests in the region are mutually reinforcing: security and growth make it more likely that human rights will be honored and democracy will emerge" (104); 3) the Pacific Rim is collectively the United States' largest trading partner, with $40 \%$ of global bank reserves in seven leading East Asian economies, and U.S. "reliance on these and other sources of foreign capital further underscores" the region's importance to the U.S. (104); and 4) U.S. strategy is "based on enlarging the community of market democracies .... [I]ts central goals are: to enhance security by maintaining a strong defense capability and promoting cooperative security measures ... to open foreign markets and spur global economic growth ... and to promote democracy abroad" (105). Most tellingly, in the opening remarks of the report, Assistant Secretary Nye went so far as to equate U.S. military power with the oxygen the East Asia region needed to breathe. Nye wrote: "Security is like oxygen ... You do not tend to notice it until you begin to lose it. The American security presence has helped provide this 'oxygen' for East Asian development' (104). The strategy contained all the frames of U.S. foreign policy sketched above, namely, the importance of market penetration and economic growth, the need for preponderant U.S. power to secure it, and an ideology that combined the inevitability of a certain version of political and economic modernity alongside the necessity (existential, according to Nye) of U.S. presence and leadership.

In essence, the strategy signaled that despite the enormous changes that had occurred in the region during and after the Cold War, Washington would continue to operate under familiar assumptions. In the words of Chalmers Johnson, the Pentagon's "Ossified Strategy," had "declared that nothing essential has changed 
in East Asia and that U.S. policy should be to freeze relations in the Pacific indefinitely" (Johnson 1995, 103). Put differently, while the containment or contest-ofpower logic may have dissolved with the Soviet Union, the hierarchical, relationof-domination logic had not. Nevertheless, Johnson may have overstated the case insofar as U.S. strategists did, in fact, begin to alter their thinking as a result of new realities. The aforementioned national security strategies and basing studies indicated that the nature of the security environment was evolving, from one of conventional, state-based threats to one marked by intra-state breakdown, nonstate actors, and the proliferation of weapons of mass destruction (WMD). Consonant with this shift was a movement from the Cold War era "consolidated defense in depth" to an "expeditionary defense in depth"; a shift from large, defensively oriented forward deployments, to more regionally focused, responsive, and mobile force deployments (Pettyjohn 2012, 84).

This reached its apogee, following the September $11^{\text {th }}$ terrorist attacks, in the Bush Administration's 2004 Global Defense Posture Review (GDPR). While statebased threats remained, the administration focused on a diverse set of challenges, including asymmetric threats and the use of WMD by rogue states or non-state actors. According to the GDPR, "the most important characteristic of the security environment was uncertainty and that the United States needed to develop a flexible forward presence that would enable it to project power wherever threats might emerge" (Pettyjohn 2012, 87). This required a combination of preexisting forward deployed troops and military bases, as well as the use of relationships, security cooperation activities, and the ability to quickly move forces forward.

On this point, it is instructive to note the similarity between the aforementioned plans for flexible perimeter defense in depth of the early 1940s, with the strategic vision embodied in the 2004 GDPR. In both instances, the U.S. lacked a distinct peer competitor and faced uncertainty regarding who would pose a threat in the future or from whence it might come. Nevertheless, despite (or because of) this lack of certainty, it was as much the case in 2004 as in 1943 that the first line of defense was seen to be abroad and that the threat posed by potential adversaries was "so great that the United States must adopt a global posture and take action to prevent conflict and surprise attack" (U.S. JCS 2004, 2; Pettyjohn 2012). Furthermore, the need for preponderance was also bound up with the need to secure economic interests and stability. Similar to the 1943 basing study, in the 2004 United States National Security Strategy, the global role of the U.S. military was crucial for "securing strategic access to key regions, lines of communication and the "global commons" (U.S. JCS 2004, 1). Policymakers and strategists in both eras "wanted to balance a commitment to defense in depth to meet any emerging threats along with a continuous forward presence to meet persistent challenges and to facilitate economic growth" (Pettyjohn 2012, 95). The context had changed, but the imperatives remained the same. 
Such a strategy, by definition, called for continued U.S. predominance, but also worked against the use of existing multilateral institutions or the need to develop new ones. Multilateral institutions were too cumbersome and would dilute the full range of options open to ascendant U.S. power. Rather, focus centered on assembling groups or coalitions of countries under U.S. leadership. Chalmers Johnson's criticism that nothing had changed was correct to the extent that U.S. strategists' guiding assumptions remained fixed. They recognized new threats and faced increasing uncertainties, but the drive for U.S. global preponderance had not abated.

In the post-Cold War interregnum, this translated into a U.S. security policy focused on maintaining a longstanding hierarchical position in the region. To be sure, U.S. elites were aware of the remarkably transformed strength of their allies. Moreover, due to reduced threat perceptions, budget constraints, and demands for a peace dividend they pushed Japan and South Korea to assume greater responsibility in each alliance (Yang 2015). Additionally, both allies desired a greater security role, either to enhance their autonomy (ROK) or international reputation (Japan) (Easley 2007). Nevertheless, these plans were either delayed and longstanding arrangements stayed in place, or the more robust international security role of each country remained an outgrowth of alliance-based cooperation, which is to say still embedded within hierarchical bilateralism (Weitz 2013a; Przystup 2013; Snyder 2012).

Crafting new multilateral institutions would have required not only acknowledging the enormous changes that had occurred (which, to be fair, U.S. officials did do), but, more importantly, incorporating those changes in a more equitable and realistic fashion. This directly cut against the underlying drive for U.S. preponderance, and did so during what some U.S. elites viewed as their unipolar moment (Krauthammer 1991). For them, U.S. power was to be asserted unabashedly rather than hemmed in by multilateral institutions. Thus, in essence, U.S. policy elites remained tethered to what Ikenberry refers to as "rule through relationships" in respect to their East Asian allies (Ikenberry 2011, 87). We turn now to brief examination of the East Asian economic crisis, focusing in particular on how the U.S. response exhibited the frames sketched above.

\section{The East Asian Economic Crisis: The Inevitable Comeuppance}

The same frames evident in U.S. security policy were present in the U.S. response to the East Asian economic crisis, which is to say: a faith in free markets and a need for market expansion; a drive for U.S. preponderance (not in military terms, but as a universal political-economic model); and an exceptionalist ideology, which perceived the crisis as the cost of opposing the "natural order of things" as well as evidence of the inevitable success of convergence under an unregulated 
market mechanism (Williams 2009, xii). For U.S. elites, their diagnosis of the cause and solution to the economic crisis were bound up with enduring beliefs. Gilpin is worth quoting at length on this point:

The twin beliefs that economic convergence will occur and unregulated markets will effectively guide the world are very much a product of the outstanding success of the American economy in the 1990s. The rest of the world, proponents of this position argue, should emulate what they regard as the reasons for America's unprecedented growth, namely, deregulate markets and minimize the role of the government in the economy ... As Treasury Secretary Paul O'Neill informed a Group of Seven financial officials in February 2001 ... [a] financial or currency crisis such as that of East Asia in 1997 ...' doesn't have anything to [do] with the failure of capitalism. It's to do with an absence of capitalism.' In a world economy based on self-regulating markets, according to this perspective, international cooperation and international institutions are largely unnecessary (Gilpin 2003, 80; emphasis added).

The cause of the economic crisis was not too much capitalism, but not enough. The rapid opening of financial markets in countries with underdeveloped currency controls was not the problem, but government intervention in currency and other markets was. From this perspective, the crisis proved that the so-called East Asian model, which U.S. elites had reviled, feared, and even come to admire, was, in fact, at its end. Alan Greenspan, Chairman of the Federal Reserve Board at the time, stated that one "result of the current economic turmoil in Asia is that the Asians are being moved toward American practices" (Cited in Hellman 2003, 33). Ultimately, there could be only one model.

Unsurprisingly, then, if a lack of capitalism and government intervention in markets was the cause of the crisis, then the solution had to involve structural reforms that removed the corrupt and market distorting hand of government bureaucrats. As Hellman (2003) notes, for U.S. and other Western elites, this would require only slight adjustment to existing multilateral institutions, not the creation of new ones. The logic was clear. The countries in question faced economic crisis because they deviated from the dictates of free enterprise; creating new institutions that incorporated their particular variants of capitalism would only legitimate a model that was by its very nature illegitimate. If the end point was inevitable, why create new institutions? If the American model were "the end of history," then the existing framework would do (a framework, incidentally, that the Americans dominated) (Fukuyama 1989).

What this meant in practice was that convergence would "be forced by policies and power," which exhibited a stunning "ahistorical hubris and intellectual myopia" (Hellman 2003, 34). The specific historical, social, and cultural context within 
which each East Asian economy was embedded was both ignored yet also assumed to be easily malleable in response to external dictates. Moreover, Asian-led attempts at organization or institution building were either given short shrift or staunchly opposed (Stiglitz 2003; Lee 2006).

\section{QUALIFICATIONS}

\section{A General Outlook and Current Relevance}

This article has examined one of the more important elements of the postCold War interregnum, namely, the absence of a real diplomatic or political effort on the part of the United States to build new multilateral institutions that more accurately reflected the remarkably transformed distribution of power in the international system and in East Asia specifically. It did so by sketching three interconnected and historically rooted frames of U.S. foreign policy, and showing how they were manifest in both U.S. security policy and the U.S. response to the East Asian economic crisis in ways that worked against the development of new multilateral institutions.

As intended, the frames and their application to U.S. policy in post-Cold War East Asia were drawn in a relatively broad and heavily U.S.-centric fashion. The argument above should not be construed as a claim that all U.S. policy elites agree with these frames or that there are not intense disagreements among them regarding specific foreign policies. That would be empirically absurd. Rather, the frames sketched above are representative of a general and enduring outlook or orientation, grounded in American history and reconstituted within constantly shifting historical contexts. Additionally, the preset study does not preclude the causal value of the other historical and structural variables outlined in the introduction. Such analysis motivates further exploration of how these frames influenced more recent policies as well as the U.S. relationship with particular East Asian countries. In what follows, a brief examination of the so-called U.S. pivot or strategic rebalance to the region is provided, highlighting the expansive and familiar frames behind it, as well as their operation in specific security and economic areas.

The U.S. rebalancing toward the Asia Pacific followed nearly a decade of abject failure in the Middle East. The Bush Administration's 2003 U.S. invasion of Iraq was driven by a highly militarized, even messianic American exceptionalism, whereby U.S. forces, as Wilsonians under Arms, would use coercion to bring democracy to and change the way people lived in the Middle East (Bacevich 2013; 2016). Upon entering office in 2009, President Obama assumed a far less rhetorically unabashed and unilateralist foreign policy. Nevertheless, in turning its attention to the Asia Pacific region, the Obama Administration quickly employed time-honored frames to justify the shift. 
Similar to earlier policy statements, such as the 1994 Nye Report and the 2004 GDPR, President Obama's 2011 remarks before the Australian Parliament echoed the language and rationales underpinning the frames analyzed above: first, there was the imperative of free-market, economic expansion and its direct relevance to stability at home; second, security was necessary for prosperity and peace, and an enhanced U.S. military presence and use of alliances was necessary to achieve that security; and, third, there was invocation of the special American role as both representative of and leader for the promotion of universal rights and human dignity (Obama 2011). In her 2013 address, "America's Future in Asia," Obama's then National Security Advisor Susan Rice reinforced these themes, stating that the U.S. rebalance would lay the foundations for: "enhancing security, expanding prosperity, fostering democratic values, and advancing human dignity" (Rice 2013) In short, the U.S. would stay true to what Jentleson (2014) calls the four core goals that define U.S. national interest: Power, Peace, Prosperity, and Principles.

In the context of the pivot, U.S. efforts in regional ballistic missile defense exhibit some of these themes. Playing the role of the outside and preeminent broker, the U.S. has tightened what Cha (1999) referred to as a quasi-alliance between its Japanese and South Korean partners. It has done so by increasing the deployment of advanced U.S. BMD assets to Japanese and Korean soil, fostering intelligence sharing agreements between its two allies, and pursuing combined military exercises aimed at increasing interoperability of trilateral US-Japan-ROK defense systems (Weitz 2013b). In essence, the U.S. has utilized its still superordinate, hierarchical position to repurpose its Cold War hub-and-spokes system to new purpose. Moreover, Wingerter (2011) shows how the deployment of U.S. missile defense and related space-based weapons is also driven by, among other factors, the massive profits of domestically influential military-industrial contractors and an ideology that sees these deployments and U.S. dominance in these areas (regardless of technical feasibility) as necessary to ensure its prestige and strength. Unsurprisingly, these developments have spurred recriminations from Pyongyang, Beijing, and Moscow.

In economic policy, the U.S.-led Trans-Pacific Partnership (TPP) similarly reflects the frames in question. Although a complex issue, the TPP is in part a U.S. effort to solidify and increase its economic position in the region as against China's notable economic rise. More specifically, the TPP embodies the American vision of the proper type of political economy, involving open and transparent financial markets. While it is theoretically open to new entrants, the "high quality" nature of the agreement makes China's entry difficult if not impossible due to its still relatively opaque financial sector and the continued important of state-owned enterprises (SOEs) (Work 2014).

Similar dynamics were at work in the U.S. opposition to the China-led Asian 
Infrastructure Investment Bank (AIIB). It was reported that American officials lobbied against it "with unexpected determination and engaged in a vigorous campaign to persuade important allies to shun the project" (Perlez 2014). They viewed it both as challenge to U.S. dominated institutions like the World Bank, as well as Chinese "soft-power play that promises economic benefits to polish its image" despite aggressive territorial claims in the region (Perlez 2014). By way of conclusion, a brief review of Ikenberry (2011) is offered as final support for the argument above.

\section{CONCLUSION}

\section{Liberal Stability of Hierarchical Predominance?}

Ikenberry $(2011,26)$ described the U.S.-led postwar international order as one of "mixed character," with U.S. rule broken down into essentially three "realms of American domination" or three "variations in hierarchy." Within each realm a distinct and divergent logic of order predominates, all of which, "are strategies that a dominant state can use in efforts to assert control over the international environment" (90). These variations represent a continuum of logics of order characterized as follows: consensual multilateralism; a hub-and-spoke system of asymmetrical dependency; and coercive imperialism. The first realm (consensual multilateralism) is based on "rule through rules," wherein "open and loosely-rule based" relations among states are institutionalized in "constitutional structures" (84). This realm applies to U.S. relations with the developed, industrial democracies of Western Europe and the multilateral institutions within which they are embedded.

The second realm (asymmetrical dependency) is based on what Ikenberry calls "rule through relationships" (87). The logic of order in this realm mirrors the patron-client relationships Scott (1972) examines in his ethnographic work in Southeast Asia, only writ large onto the international stage. Within this realm, a dominant state establishes asymmetrical bilateral relationships with weaker and secondary states, or more specifically, with elites within these states. The dominant state wields its greater military, economic and political power in order to assert more explicit control over these states. The relationship does include reciprocal exchange, but it is unequal and possibly coercive in nature. Historically, the U.S.Japan and U.S.-South Korean alliance fall within this realm. Despite the enormous shifts that have occurred within Japan and South Korea during and after the Cold War, and the more significant role each has taken on in their respective alliance as well as the international system, the fundamental hierarchy of these relationships remains intact.

Ikenberry sums up the third realm, "coercive imperialism," as follows: "the coercive enforcement of rule by the dominant state lurks in the background, 
circumscribing sovereignty and the limits of political choice within the subordinate state" (Ikenberry 2012, 88). The logic of order in this realm is pure domination based on the constant threat of violence. The third realm includes the peripheral and underdeveloped parts of the world; in other words, the majority of the earth's land and resources, and 85\% of the world's population (Betts 2011).

The central point is that the U.S. created and institutionalized a consensual multilateral order only for a select few countries, all of which approximated its own political, cultural, and economic make-up. Moreover, the U.S. institutionalized its power and made short-term concessions, mainly in order to lock-in its predominant position for the long-term. Also, it created these new multilateral institutions following the vast dislocations of a hegemonic war and in the face of a growing Soviet threat. However, for East Asia, the U.S. designed and institutionalized far more hierarchical relationships, based on geostrategic considerations, asymmetrical dependence and truncated sovereignty (Cumings 1999; Cha 2009). Furthermore, for the overwhelming majority of the world, the U.S. engaged in either complete neglect or outright coercion and violence. As Ikenberry states, in much of the world, "American involvement has often been crudely imperial" (Ikenberry 2012, 27). In short, Ikenberry's framework helps show how and why the U.S. established the order it did with the advanced industrial democracies, but leaves out the majority of the world in which U.S. behavior remains hierarchically oriented if not openly coercive and patently illiberal (Hobson 2012).

In closing, the argument here is not that lack of U.S. initiative following the Cold War is the main or sole reason for the absence of new multilateral institutions in East Asia. It is not certain that had the U.S. attempted to construct them, new multilateral institutions would have been successfully established. The structural and historical factors outlined in the introduction would have complicated even strenuous U.S. efforts. Moreover, Ikenberry $(2001,259)$ notes that, in addition to the need for power being highly concentrated in the hands of a single state, the institutional bargain is "most wanted and available" where democratic states can establish credible restraints and commitments. In this vein, when comparing Western Europe's successful institutionalization of multilateral security cooperation against its relative absence in Northeast Asia, Howe (2007) stresses the restraining effect of pluralistic democracies, international organizations, and a regional normative community. At the end of the Cold War and today, Northeast Asia and East Asia generally lack these attributes.

Nevertheless, as Ikenberry has shown $(2001 ; 2011)$ a necessary condition for the establishment of new institutions is not only for power to be highly concentrated in the hands of a single state but also for that state to actively pursue an institutional bargain. Speaking of more recent events and specifically about Northeast Asia, yet still echoing the point, Howe $(2007,43)$ writes that: "U.S. leadership will be required to realize a multilateral security and cooperation forum." Despite this, 
the U.S. has not put forth the requisite diplomatic or political effort in post-Cold War East Asia. The foregoing analysis examined three frames of U.S. foreign policy that help to explain why. As noted, these frames, and their ensuing U.S. security and economic policies, were situated within a constellation of other structural and historical variables. Like the post-World War II settlement, U.S. power was dominant. Unlike that juncture, though, the U.S. did not face a new peer competitor, its vision of political modernity (i.e. democratic, free-market capitalism) appeared ascendant, and the rest of the world converged around it. Such an outcome fits squarely with its teleological, exceptionalist ideology. Furthermore, the U.S. imperative for preponderant power, long institutionalized in asymmetrical bilateral relationships throughout the region, would give it ultimate discretion as it awaited the inevitable. In this context, and driven by these imperatives and ideology, new multilateral institutions were merely superfluous.

\section{REFERENCES}

Anderson, Perry. 2013. "Imperium." New Left Review 83: 5-111.

Autesserre, Severine. 2009. "Hobbes and the Congo: Frames, Local Violence, and International Intervention.” International Organization 63(2): 249-280.

Bacevich, Andrew J. 2008. The Limits of Power: The End of American Exceptionalism. New York: Metropolitan Books.

Bacevich, Andrew J. 2013. The New American Militarism: How Americans Are Seduced by War. New York: Oxford University Press.

Bacevich, Andrew J. 2016. America's War for the Greater Middle East: A Military History. New York: Random House.

Betts, Richard K. 2011. "Institutional Imperialism.” National Interest 113: 85-96. Caldwell, Curt. 2011. NSC-68 and the Political Economy of the Early Cold War. New York: Cambridge University Press.

Cha, Victor. 1999. Alignment Despite Antagonism: The United States-Korea-Japan Security Triangle. Stanford, CA: Stanford University Press.

Cha, Victor. 2009. "Power play Origins of the U.S. Alliance System in Asia." International Security 34(3): 158-196.

Cumings, Bruce. 2010. The Korean War: A History. New York: Modern Library.

Cumings, Bruce. 1992. "The Wicked Witch of the West is Dead, Long Live the Wicked Witch of the East." In The End of the Cold War: Its Meanings and Implications edited by Michael J. Hogan, 87-102. Cambridge: Cambridge University Press.

Cumings, Bruce. 1999. Parallax Visions: Making Sense of American-East Asian Relations at the End of the Century. Durham: Duke University Press.

Easley, Leif-Eric. 2007. "Defense Ownership or Nationalist Security: Autonomy and Reputation in South Korean and Japanese Security Policies." SAIS Review 27 
(2): 153-166.

Ekbladh, David. 2011. The Great American Mission: Modernization and the Construction of an American World Order. Princeton: Princeton University Press.

Fukuyama, Francis. 1989. "The End of History?" The National Interest 16: 3-18.

Gaddis, John L. 1997. We Now Know: Rethinking Cold War History. Oxford: Clarendon Press.

Gaddis, John L. 2004. Surprise, Security, and the American Experience. Cambridge: MA: Harvard University Press.

Gaddis, John L. 2005. Strategies of Containment: A Critical Appraisal of American National Security Policy During the Cold War. New York: Oxford University Press.

Gardner, Lloyd C. 1993. Spheres of Influence: The Great Powers Partition Europe, from Munich to Yalta. Chicago: I.R. Dee.

Gilpin, Robert. 1981. War and Change in World Politics. Cambridge; New York: Cambridge University Press.

Gilpin, Robert. 1997. "APEC in a New International Order." In From APEC to Xanadu: Creating a Viable Community in the Post-Cold War Pacific edited by Donald C. Hellman and Kenneth B. Pyle. Armonk: M.E. Sharp: 14-36.

Gilpin, Robert. 2003. "A Postscript to the Asian Financial Crisis: The Fragile International Economic Order." Cambridge Review of International Affairs 16(1): 79-88.

Goffman, Erving. 1974. Frame Analysis: An Essay on the Organization of Experience. Cambridge, MA: Harvard University Press.

Gruber, Lloyd. 2001. "Power Politics and the Free Trade Bandwagon." Comparative Political Studies 34(7): 703-741.

Hellman, Donald C. 2003. "In the Wake of the East Asian Economic Crisis: Toward an Interdependent but Non-Convergent Global System." Cambridge Review of International Affairs 16(1): 33-48.

Hobson, John M. 2012. The Eurocentric Conception of World Politics: Western International Theory, 1760-2010. Cambridge: Cambridge University Press.

Hogan, Michael J. 2000. A Cross of Iron: Harry S. Truman and the Origins of the National Security State, 1945-1954. Cambridge, U.K: Cambridge University Press.

Howe, Brendan. 2007. "International Organizations and Institutions in Northeast Asia." The Korean Journal of Security Affairs 12(2): 19-43.

Hunt, Michael H. 2009. Ideology and U.S. Foreign Policy. New Haven, CT: Yale University Press.

Ikenberry, G. John. 2000. After Victory: Institutions, Strategic Restraint, and the Rebuilding of Order after Major Wars. Princeton, N.J: Princeton University Press.

Ikenberry, G. John. 2011. Liberal Leviathan: The Origins, Crisis, and Transforma- 
tion of the American World Order. Princeton, N.J: Princeton University Press. Jentleson, Bruce W. 2014. American Foreign Policy: The Dynamics of Choice in the $21^{\text {st }}$ Century. New York; London: W.W. Norton and Company.

Jervis, Robert. 2006. "Understanding Beliefs." Political Psychology 27(5): 641-63. Johnson, Chalmers and E. B. Keehn. 1995. The Pentagon's Ossified Strategy. Foreign Affairs 74(4): 103-114.

Kennan, George. 1946. "George Kennan to James Byrnes ['Long Telegram']," in The Harry S. Truman Library and Museum, accessed May 25, 2016, http:// www.trumanlibrary.org/whistlestop/study_collections/coldwar/documents/in dex.php?documentid $=6$-6\&pagenumber $=1$.

Kennan, George F. ('X') 1947. "The Sources of Soviet Conduct." Foreign Affairs 25 (4): 566-582.

Keohane, Robert. 1984. After Hegemony: Cooperation and Discord in the World Political Economy. Princeton, N.J: Princeton University Press.

Kindig, Jessie L. 2014. "War for Peace: Race, Empire, and the Korean War." (Ph.D. dissertation, University of Washington at Seattle).

Kolko, Gabriel. 1968. The Politics of War: The World and United States Foreign Policy, 1943-1945. New York: Random House.

Kramer, Paul A. 2006. The Blood of Government: Race, Empire, the United States, and the Philippines. Chapel Hill: University of North Carolina Press.

Krauthammer, Charles. 1991. "The Unipolar Moment.” Foreign Affairs 70(1): 23-33. Kwak, Kwang Sub. 2005. "The United States-ROK Alliance, 1953-2004: Alliance Institutionalization.” (Ph.D. dissertation, Southern Illinois University at Carbondale).

Kwon, Heonik. 2010. The Other Cold War. New York: Columbia University Press. Laidi, Zaki. 1998. A World Without Meaning: A Crisis of Meaning in International Politics. New York: Routledge.

LaFeber, Walter. 1997. The Clash: A History of U.S. Japan Relations. New York: W.W. Norton and Company.

Larson, Eric V., David T. Orletsky, and Kristin Leuschner. 2001. Defense Planning in a Decade of Change: Lessons from the Base Force, Bottom-up Review, and Quadrennial Defense Review. Santa Monica, CA: RAND Corporation.

Lee, Yong Wook. 2006. "Japan and the Asian Monetary Fund: An Identity-Intention Approach.” International Studies Quarterly 50(2): 339-366.

Leffler, Melvyn P. 1992. A Preponderance of Power: National Security, the Truman Administration, and the Cold War. Stanford: Stanford University Press.

Leffer, Melvyn P. 1994. The Specter of Communism: The United States and the Origins of the Cold War, 1917-1953. New York: Hill and Wang.

McCormick, Thomas J. 1995. America's Half Century: United States Foreign Policy in the Cold War and After. Baltimore: Johns Hopkins University Press. McMahon, Robert J. 2013. The Cold War in the Third World. Oxford; New York: 
Oxford University Press.

Na, Jongnam. 2006. "Making Cold War Soldiers: The Americanization of the South Korean Army." (Ph.D. dissertation, University of North Carolina at Chapel Hill).

Niebuhr, Reinhold. 2008. The Irony of American History. Chicago: University of Chicago Press.

Obama, Barack. 2011. "Remarks by President Obama to the Australian Parliament." in The White House: Office of the Press Secretary, last modified November 17, 2011, accessed May 15, 2016, https://www.whitehouse.gov/the-pressoffice/2011/11/17/remarks-president-obama-australian-parliament.

Pettyjohn, Stacie. 2012. U.S. Global Defense Posture, 1783-2011. Santa Monica, CA: RAND Corporation.

Perlez, Jane. 2014. U.S. “Opposing China's Answer to World Bank.” in New York Times, last modified October 9, 2014, accessed May 25, 2016, http://www. nytimes.com/2014/10/10/world/asia/chinas-plan-for-regional-development-b ank-runs-into-us-opposition.html?_r $=0$.

Pierpaoli, Paul G. 1999. Truman and Korea: The Political Culture of the Early Cold War. Columbia, MO: University of Missouri Press.

Przystup, James J. 2013, "Change and Continuity: The U.S.-ROK Alliance at 60." Korean Journal of Defense Analysis 25(4): 561-566.

Rice, Susan E. 2013. "Remarks as Prepared for Delivery by National Security Advisor Susan E. Rice." In The White House: Office of the Press Secretary, last modified November 21, 2013, accessed May 15, 2016, https:/www. whitehouse.gov/the-press-office/2013/11/21/remarks-prepared-delivery-natio nal-security-advisor-susan-e-rice.

Scott, James C. 1972. "Patron-Client Politics and Political Change in Southeast Asia." American Political Science Review 66(1): 91-113.

Snyder, Scott. 2012. The US-South Korea Alliance: Meeting New Security Challenges. Boulder, CO: Lynne Rienner Publishers.

Stephanson, Anders. 2011. "Kennan: Realism as Desire." In The Invention of International Relations edited by Nicolas Guilhot, 162-181. New York: Columbia University Press.

Stiglitz, Joseph E. 2003. Globalization and Its Discontents. New York: W.W. Norton.

Turse, Nick. 2013. Kill Anything That Moves: The Real American War in Vietnam. New York: Metropolitan Books/Henry Holt.

US Department of Defense. 1990. A Strategic Framework for the Asia Pacific Rim: Looking for the $21^{\text {st }}$ Century. Washington, D.C: US GPO.

US Department of Defense. 1995. The United States Security Strategy for the East Asia-Pacific Region. Washington, D.C: US GOP.

US Joint Chiefs of Staff. 2004. The National Military Strategy of the United States 
of America: A Strategy for Today; A Vision for Tomorrow. Washington, D.C: Office of the Joint Chiefs of Staff.

US President. 1991. National Security Strategy of the United States. Washington D.C: White House.

Weick, Karl E. 1995. Sensemaking in Organizations. Thousand Oaks, CA: Sage Publishing.

Weitz, Richard. 2013a. "An Enduring Partnership: South Korea and the United States.” Korean Journal of Defense Analysis 25(3): 301-315.

Weitz, Richard. 2013b. "US Missile Defense Program and Its Asian Implications." In The Asan Institute of Policy Studies, last modified October 30, 2013, accessed November 10, 2013, http://en.asaninst.org/contents/us-missile-defenseprogram-and-its-asian-implications/.

Westad, Odd Arne. 2005. The Global Cold War: Third World Interventions and the Making of Our Times. Cambridge: Cambridge University Press.

Williams, William Appleman. 1961. The Contours of American History. Cleveland: World Publishing.

Williams, William Appleman. 2007. Empire as a Way of Life: An Essay on the Causes and Character of America's Present Predicament along with a Few Thoughts about an Alternative. Brooklyn, N.Y: Ig Publishing.

Williams, William Appleman. 2009. The Tragedy of American Diplomacy. New York: Dell Publishing.

Wingerter, Rex. 2011. "What Drives the Development of US Missile Defense and Space-Based Weapons? The Role of US Domestic Interest Groups." Asian Perspective 35(4): 559-594.

Work, John Clinton. 2014. "New Asian Economic Order." In 2014 Asan Plenum Proceedings Book, last modified November 14, 2014, accessed May 25, 2016, http://en.asaninst.org/contents/asan-plenum-2014-proceedings/.

Yang, Hee Yong. 2015. "The Change in US Security Role Prescriptions towards Its Northeast Asian Allies at the Outset of the Post-Cold War Era." The Korean Journal of Security Affairs 20(2): 48-74.

Yergin, Daniel. 1991. The Prize: The Epic Quest for Oil, Money, and Power. New York: Simon and Schuster. 